\title{
KEMATANGAN TERMAL DAN ESTIMASI KANDUNGAN MINYAK ENDAPAN SERPIH FORMASI SINAMAR DI DAERAH DUSUN PANJANG, PROVINSI JAMBI
}

\section{THERMAL MATURITY AND OIL CONTENT ESTIMATE FROM SHALE IN SINAMAR FORMATION AT DUSUN PANJANG AREA, JAMBI PROVINCE}

\author{
Robet Lumban Tobing \\ Pusat Sumber Daya Mineral Batubara dan Panas Bumi \\ Jalan Soekarno Hatta No. 444, Bandung \\ trebor_dim@yahoo.co.id
}

\begin{abstract}
ABSTRAK
Formasi Sinamar diperkirakan berumur Oligosen berada pada Cekungan Busur Belakang. Dari hasil pemetaan geologi di lapangan ditemukan 14 lokasi singkapan serpih dengan ketebalan berkisar 10 hingga $>25$ meter. Secara megaskopis, conto serpih berwarna abu-abu kecoklatan hingga abu-abu kehitaman, struktur laminasi, menyerpih, keras-getas, setempatsetempat terdapat sisipan batupasir berbutir halus berwarna abu-abu kecoklatan. Berdasarkan data hasil analisis pirolisis dan maseral yang dilakukan pada 14 conto serpih mengindikasikan bahwa serpih tersebut mengandung material organik berkisar antara $0,14 \%$ hingga 16,95\%, didominasi oleh kerogen Tipe I dan Tipe II yang memiliki kecenderungan untuk menghasilkan minyak. Secara mikroskopis, material-material organik tersebut terdiri dari maseral liptinit dan vitrinit berkisar antara $<0,1$ hingga 9,99\% dan maseral inertinit antara $<0,1$ hingga $0,49 \%$. Tingkat kematangan material organik dikategorikan belum matang (immature) hingga lewat matang (over mature). Berdasarkan data hasil analisis fischer assay yang dilakukan terhadap conto serpih diperoleh kandungan minyak dengan kisaran 5 hingga 90 liter minyak/ton serpih. Dari hasil penghitungan yang dilakukan dapat diperkirakan bahwa sumber daya serpih di daerah penelitian sebesar 317.081 .582 ton serpih dengan volume minyak sebesar 69.535.298 barel.
\end{abstract}

Kata kunci: Kematangan termal, material organik, pirolisis, fischer assay

\section{ABSTRACT}

The Oligocene Sinamar Formation is located in the Back Arc Basin. From the results of geological mapping, there have been found 14 outcrop shale locations with thickness about 10 to $>25$ meters. The characteristic of shale is brownish gray to blackish color, lamination structures, and hard to brittle. Locally, there is some intercalation of fine grain sandstone with gray to brown color. The results of pyrolysis and maceral analyses on 14 samples of shale indicatedthe organic material content about $0.14 \%$ to $16.95 \%$ that is dominated by kerogen type I and type II which could produce oil prone. Microscopically, the organic material consists of maceral liptinite and vitrinite about $<0.1 \%$ to $9.99 \%$ and maceral inertinite about $<0.1 \%$ to $0.49 \%$. The level of maturity from the organic material is categorized as immature to over mature. Based on the analysis of fischer assay conducted on rock samples obtained oil about 5 to 90 liter of oil/ton of shale. Therefore it can be estimated that shale resources is about $317,081,582$ ton and volume of oil is about 69,535,298 barrel.

Keywords: thermal maturity, organic material, pyrolysis, fischer assay

\section{PENDAHULUAN}

Serpih merupakan batuan sedimen halus yang sebagian besar berasal dari darat dan mengandung mineral lempung dalam jumlah yang cukup besar (Schieber, 2011). Sedangkan istilah serpih minyak didefinisikan sebagai batuan sedimen 
halus yang mengandung material organik yang dapat menghasilkan minyak ketika di ekstrak (Yen and Chilingarian, 1976; Hutton, 1987, 2006; Suarez, dkk, 2012). Proses ekstrak serpih ini biasanya disebut dengan istilah Fischer assay, yaitu suatu proses pemanasan serpih pada temperatur $298^{\circ} \mathrm{K}$ hingga $773^{\circ} \mathrm{K}\left(25^{\circ} \mathrm{C}\right.$ hingga $\left.500^{\circ} \mathrm{C}\right)$ selama lebih kurang 50 menit untuk menghasilkan minyak (Lee, dkk, 2007). Serpih minyak sering juga disebut sebagai black shale atau brown shale tergantung dari warna endapan serpih tersebut. Komponen mineral serpih umumnya terdiri dari mineral lempung, felspar, karbonat, sulfida dan oksida mineral (Crisp, dkk., 1987 ; Slatt dan Rodriguez, 2012).

Tujuan dari tulisan ini adalah untuk mengetahui kematangan termal dan estimasi kandungan minyak endapan serpih Formasi Sinamar. Lokasi penelitian secara administratif berada di Kabupaten Bungo, Provinsi Jambi. Koordinat geografis daerah penelitian berada pada 101 $42^{\prime}$ 101'58' BT dan 01²3'-01'40' LS (Gambar 1).

Metode yang digunakan dalam penelitian ini adalah pemetaan singkapan batuan di lapangan, pengambilan conto batuan yang diduga sebagai batuan sumber hidrokarbon dan analisis laboratorium. Analisis laboratorium terdiri dari analisis TOC (total organic carbon) dan pirolisis, analisis maseral dan reflektansi vitrinit (Rv) dengan menggunakan mikroskop sinar pantul dan analisis fischer assay.

\section{GEOLOGI DAERAH PENELITIAN.}

Morfologi daerah penelitian dibagi menjadi dua satuan yaitu morfologi perbukitan bergelombang dan pedataran. Morfologi perbukitan bergelombang menempati bagian baratdaya hingga baratlaut dan Satuan Pedataran menempati bagian utara hingga selatan daerah penelitian.
Geologi daerah penelitian mengacu pada Peta Geologi Bersistem Lembar Painan dan Bagian Timurlaut Lembar Muarasiberut yang diterbitkan oleh Pusat Penelitian dan Pengembangan Geologi, Bandung. Daerah penelitian berada pada Cekungan Busur Belakang (Back Arc Basin) (Rosidi, dkk., 1996 dalam Harahap, dkk., 2003) yang terletak di sebelah baratlaut Cekungan Sumatera Selatan (Zajuli dan Panggabean, 2013).

Stratigrafi daerah penelitian disusun oleh batuan pra-Tersier dan Tersier (Gambar 2). Batuan pra-Tersier merupakan batuan yang bertindak sebagai batuan alas, terdiri dari Formasi Palepat (Pp), Diorit (Jd) dan Granit (Jgr). Kemudian pada Kala Oligosen cekungan ini mulai terisi oleh batuan sedimen Tersier (Rosidi, dkk., 1996). Urutan stratigrafi pada daerah penelitian dari yang tertua hingga kemuda adalah:

Formasi Sinamar (Tos) berumur Oligosen, tersusun oleh konglomerat, batupasir kuarsa di bagian bawah, kemudian di atasnya ditutupi oleh batulempung, napal, batubara dan serpih. Ketebalan formasi ini diperkirakan mencapai 750 meter.

Formasi Ratauikil (Tmr) terendapkan di atas Formasi Sinamar, berumur Oligosen Akhir-Miosen, tersusun oleh batupasir, batulempung dan lensa tipis batugamping. Secara tidak selaras, di atas Formasi Rantaukil terendapkan Formasi Kasai (QTk) berumur Plio-Plistosen yang tersusun oleh tufa batuapung, batupasir tufaan dengan sisipan bentonit dan sedikit lignit. Formasi ini memiliki ketebalan berkisar 700 meter. Pada Kala Plistosen Holosen terendapkan Batuan Gunungapi Asam yang Tak Terpisahkan (Qou), Batuan Gunungapi yang Tak Terpisahkan (Qyu) dan Aluvium (Qal) terdiri dari lanau, pasir dan kerikil. Struktur geologi yang berkembang di daerah penelitian adalah sesar geser menganan (dextral) dengan arah relatif timurlaut-baratdaya. 

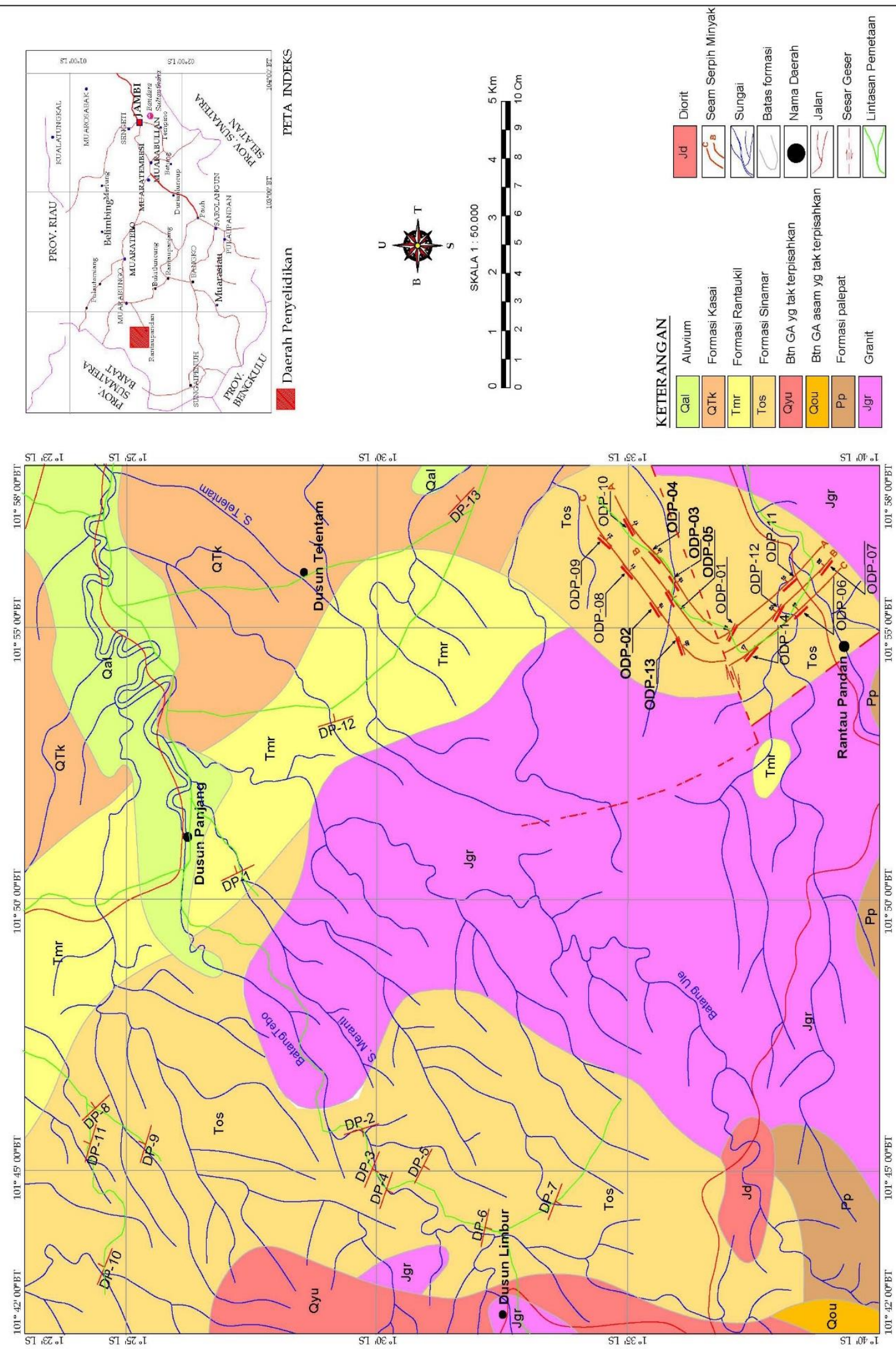

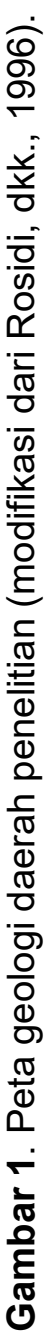




\section{MAKALAH ILMIAH}

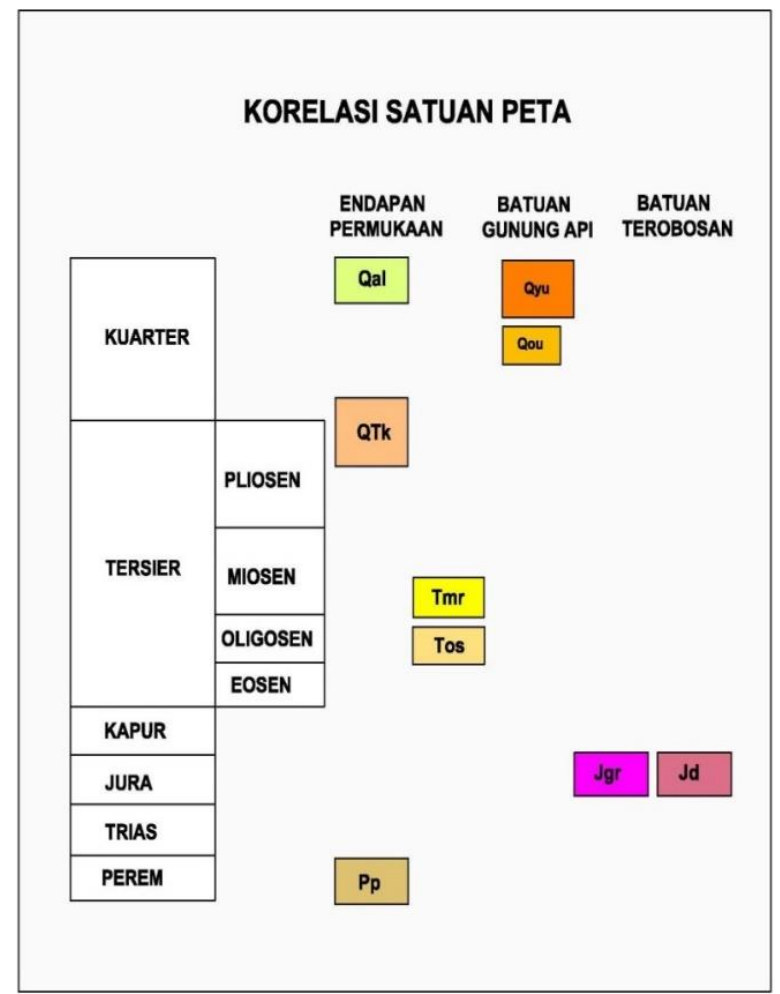

Gambar 2. Stratigrafi daerah penelitian (modifikasi dari Rosidi, dkk., 1996).

\section{HASIL ANALISIS}

Dari hasil pemetaan di daerah penelitian, ditemukan sebanyak 14 conto serpih dengan ketebalan berkisar 10 hingga $>25$ meter.

Secara mikroskopik, berdasarkan terminologi Cook (1982) maseral organik conto serpih di daerah penelitian terdiri dari maseral liptinit dan vitrinit berkisar $<0,1 \%$ hingga $2,0 \%-9,99 \%$, inertinit berkisar $<0,1 \%$ hingga $0,1 \%$ - $0,49 \%$. Nilai reflektansi vitrinit ditafsirkan berkisar 0,35\% hingga $0,98 \%$ (Tabel 1 ).

Berdasarkan hasil analisis TOC dan pirolisis pada conto serpih dari daerah penelitian, kekayaan/kelimpahan material organik berkisar 0,14\% hingga 16,95\% dengan nilai $\mathrm{T}_{\text {maks }}$ (temperatur maksimum) berkisar $418,5^{\circ} \mathrm{C}$ hingga $564,4^{\circ} \mathrm{C}$ (Tabel 1). Dari hasil analisis fischer assay yang dilakukan pada conto serpih menunjukkan bahwa conto serpih dapat menghasilkan minyak dengan kisaran sebesar 5 hingga 90 liter minyak/ton serpih (Tabel 1).

\section{PEMBAHASAN}

Formasi Sinamar berumur Oligosen, tersusun oleh konglomerat, batupasir kuarsa berbutir halus-kasar, batulempung, napal, batubara, serpih dan batugamping koral. Ketebalan formasi ini diperkirakan mencapai 750 meter (Rosidi, dkk., 1996).

Endapan serpih yang ditemukan di lokasi penelitian secara megaskopis berwarna abu-abu kecoklatan hingga abu-abu kehitaman, struktuk laminasi, menyerpih, keras-getas, setempat-setempat terdapat sisipan batupasir berbutir halus berwarna abu-abu kecoklatan. Dari hasil rekonstruksi data singkapan diperkirakan bahwa endapan serpih di daerah penelitian terdiri dari tiga lapisan dengan nontasi seam $A$, seam $B$ dan seam $C$ dengan kemiringan (dip) berkisar $15^{\circ}$ hingga $22^{\circ}$ (Tobing, 2015). Ketebalan lapisan dan kenampakkan struktur paralel laminasi pada serpih mencirikan suatu proses sedimentasi secara terus menerus dan terjadi pada lingkungan pengendapan dengan arus relatif tenang (Tissot dan Welte, 1984). 
Berdasarkan hasil analisis maseral yang dilakukan terhadap conto serpih diketahui bahwa kandungan maseral terbanyak didominasi oleh maseral liptinit. Jumlah kekayaan/kelimpahan material organik berkisar $0,14 \%$ hingga 16,95\%. Menurut Waples (1985) batuan sedimen yang memiliki kandungan material organik $<0,5 \%$ tidak memiliki potensi sebagai batuan sumber hidrokarbon, sedangkan batuan sedimen yang memiliki kandungan material organik antara 1,0\% hingga 2,0\% merupakan batuan yang cukup baik sebagai batuan sumber hidrokarbon dan material organik $>2,0 \%$ merupakan batuan yang berpotensi baik hingga sangat baik sebagai batuan sumber hidrokarbon. Dari terminologi tersebut di atas, maka ada dua conto serpih dari daerah penelitian yang tidak memiliki potensi untuk menghasilkan minyak/hidrokarbon, yaitu conto serpih dengan notasi ODP-5 dan ODP-10 yang hanya memiliki kandungan material organik $<0,5 \%$ (Tabel 1).

Plot silang antara nilai $\mathrm{HI}$ (hydrogen index) terhadap OI (oxygen index) pada diagram van Krevelen (Gambar 3) menunjukkan bahwa material organik didominasi oleh kerogen Type I dan Type II sebanyak sembilan conto dan Type III sebanyak lima conto. Kerogen adalah fraksi organik yang tidak larut dalam pelarut biasa (Tissot dan
Welte, 1984). Kerogen Type I dan Type II memiliki kecenderungan menghasilkan minyak dan kerogen Type III memiliki kecenderungan menghasilkan gas (Peters dan Cassa, 1994). Kerogen Tipe I merupakan material organik yang berasal dari alga air tawar, kerogen Tipe II merupakan material organik yang berasal dari polen, spora, lilin tanaman, resin, lemak tanaman dan alga laut sedangkan kerogen Tipe III merupakan material tumbuhan tinggi (Hutton, 2006; Waples, 1985).

Kematangan termal material organik diperoleh dari analisis pirolisis dan reflektansi vitrinit. Secara umum, awal kematangan hidrokarbon terjadi sekitar $\mathrm{Rv}=0,6 \%$ dengan nilai $\mathrm{T}_{\text {maks }} 435^{\circ} \mathrm{C}$ hingga $445^{\circ} \mathrm{C}$. Puncak kematangan terjadi pada Rv $0,65 \%$ hingga $0,9 \%$ dengan nilai $\mathrm{T}_{\text {maks }}$ $445^{\circ} \mathrm{C}$ hingga $450^{\circ} \mathrm{C}$ serta akhir kematangan terjadi pada Rv $0,9 \%$ hingga $1,35 \%$ dengan nilai $\mathrm{T}_{\text {maks }} 450^{\circ} \mathrm{C}$ hingga $470^{\circ} \mathrm{C}$ dan lewat matang terjadi sekitar $\mathrm{Rv}>1,35 \%$ dengan nilai $\mathrm{T}_{\text {maks }}>470^{\circ} \mathrm{C}$ (Peters dan Cassa, 1994). Plot silang antara nilai $T_{\text {maks }}$ dan $\mathrm{HI}$ pada diagram (Gambar 4) menunjukkan bahwa kematangan termal material organik conto serpih dikategorikan belum matang (immature) hingga lewat matang (over mature).

Tabel 1. Hasil analisis TOC, pirolisis, maseral dan reflektansi vitrinit serta analisis fischer assay conto serpih dari daerah penelitian.

\begin{tabular}{|c|c|c|c|c|c|c|c|c|c|c|c|c|c|c|c|c|}
\hline \multirow{2}{*}{ No. } & \multirow{2}{*}{$\begin{array}{l}\text { Kode } \\
\text { Conto }\end{array}$} & \multirow{2}{*}{$\begin{array}{c}\text { SG } \\
\left(\mathrm{cm}^{3} / \mathrm{gr}\right)\end{array}$} & \multirow{2}{*}{$\begin{array}{c}\text { Minyak } \\
\text { (I/ton) }\end{array}$} & \multirow{2}{*}{$\begin{array}{l}\text { TOC } \\
(\%)\end{array}$} & \multirow[t]{2}{*}{ s1 } & \multirow{2}{*}{$\frac{\mathrm{S} 2}{(\mathrm{mg} / \mathrm{g})}$} & \multirow[t]{2}{*}{ S3 } & \multirow{2}{*}{$\begin{array}{l}T_{\text {maks }} \\
\left({ }^{\circ} \mathrm{C}\right)\end{array}$} & \multirow{2}{*}{ PI } & \multirow{2}{*}{ PY } & \multirow{2}{*}{$\mathrm{HI}$} & \multirow{2}{*}{ OI } & \multicolumn{4}{|c|}{ Maseral (\%) } \\
\hline & & & & & & & & & & & & & Rv & Liptinit & Vitrinit & Inertenit \\
\hline 1 & ODP-1 & 2,5 & 0 & 1,5 & 0,18 & 1,85 & 1,49 & 435,5 & 0,09 & 2,03 & 123 & 99 & - & $<0,1$ & $<0,1$ & - \\
\hline 2 & ODP-2 & 2,8 & 5 & 4,06 & 0,29 & 20,62 & 1,1 & 437,8 & 0,01 & 20,91 & 508 & 27 & 0,48 & $<0,1$ & $<0,1$ & - \\
\hline 3 & ODP-3 & 1,8 & 40 & 16,95 & 0,89 & 76,49 & 1,15 & 428,6 & 0,01 & 77,38 & 451 & 7 & 0,53 & $2,0-9,99$ & $2,0-9,99$ & $<0,1$ \\
\hline 4 & ODP-4 & 1,6 & 20 & 9,48 & 0,31 & 2,83 & 1,38 & 425,9 & 0,10 & 3,14 & 230 & 15 & 0,48 & $0,5-1,99$ & $2,0-9,99$ & $<0,1$ \\
\hline 5 & ODP-5 & 2,7 & 10 & 0,14 & 0,15 & 0,43 & 0 & 563,9 & 0,26 & 0,58 & 297 & 0 & - & $0,5-1,99$ & $<0,1$ & - \\
\hline 6 & ODP-6 & 2,4 & 10 & 8,43 & 0,29 & 15,94 & 1,24 & 435,1 & 0,02 & 16,23 & 189 & 15 & 0,55 & $0,1-0,49$ & $0,5-1,99$ & $<0,1$ \\
\hline 7 & ODP-7 & 2,3 & 90 & 8,37 & 0,58 & 61,63 & 0,45 & 440,1 & 0,01 & 62,21 & 736 & 5 & - & $2,0-9,99$ & $0,1-0,49$ & - \\
\hline 8 & ODP-8 & 2,5 & 60 & 12,86 & 0,56 & 50,28 & 1,4 & 429,7 & 0,01 & 50,84 & 391 & 11 & 0,47 & $2,0-9,99$ & $0,1-0,49$ & $0,1-0,49$ \\
\hline 9 & ODP-9 & 2 & 60 & 11,34 & 0,56 & 49,57 & 1,41 & 432 & 0,01 & 50,13 & 437 & 12 & 0,7 & $2,0-9,99$ & $2,0-9,99$ & $<0,1$ \\
\hline 10 & ODP-10 & 2,2 & 40 & 0,23 & 0,17 & 0,46 & 0 & 564,4 & 0,27 & 0,63 & 203 & 0 & 0,98 & $2,0-9,99$ & $<0,1$ & $<0,1$ \\
\hline 11 & ODP-11 & 2,4 & 5 & 1,43 & 0,19 & 0 & 2,2 & 418,5 & 1,00 & 0,19 & 0 & 153 & 0,35 & $<0,1$ & $<0,1$ & - \\
\hline 12 & ODP-12 & 2 & 70 & 10,34 & 0,9 & 80 & 0,75 & 439,9 & 0,01 & 80,9 & 774 & 7 & - & $2,0-9,99$ & $<0,1$ & - \\
\hline 13 & ODP-13 & 2,4 & 40 & 4,47 & 0,3 & 26,41 & 1,23 & 435,9 & 0,01 & 26,71 & 590 & 27 & - & $<0,1$ & $<0,1$ & - \\
\hline 14 & ODP-14 & 2,4 & 10 & 4,9 & 0,23 & 8,98 & 0,85 & 434,4 & 0,02 & 9,21 & 183 & 17 & 0,58 & $0,1-0,49$ & $0,1-0,49$ & - \\
\hline
\end{tabular}




\section{MAKALAH ILMIAH}

Sebanyak lima conto serpih dari lokasi penelitian (notasi ODP-3, ODP-4, ODP-8, ODP-9, ODP-11) memiliki nilai $\mathrm{T}_{\text {maks }}$ berkisar $418,5^{\circ} \mathrm{C}$ hingga $432^{\circ} \mathrm{C}$, mengindikasikan bahwa conto serpih tersebut dikategorikan belum matang (immature).

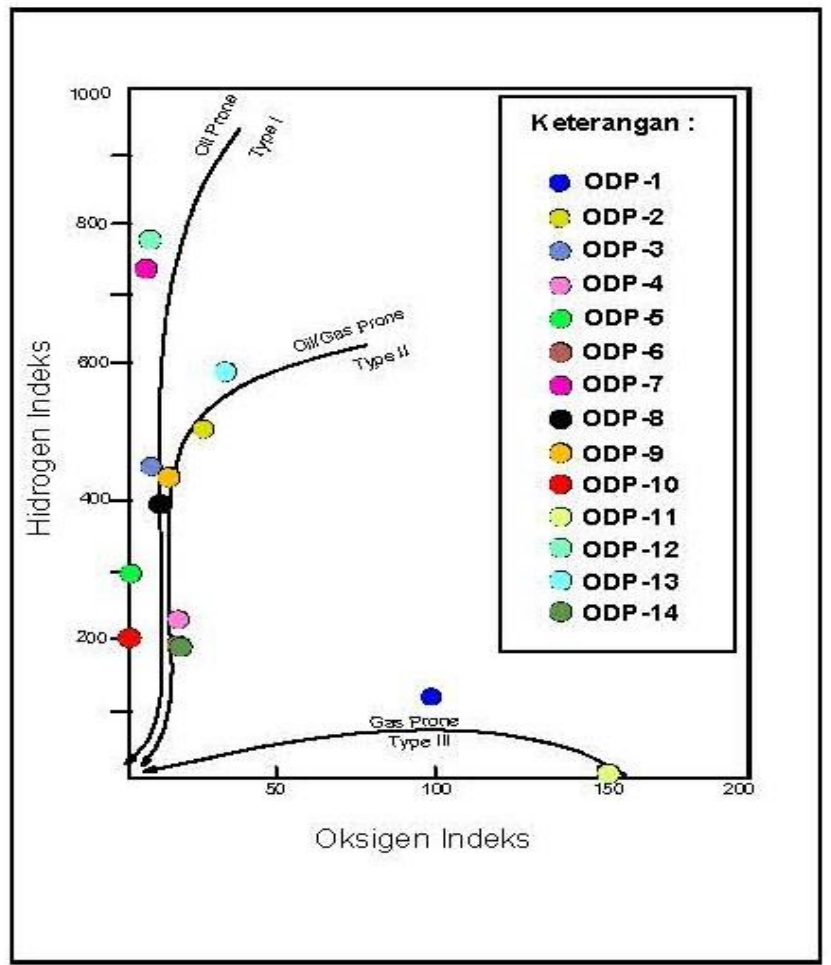

Gambar 3. Plot silang antara $\mathrm{HI}$ dan Ol pada diagram van Krevelen yang telah dimodifikasi untuk penentuan tipe kerogen (Peters dan Cassa, 1994).

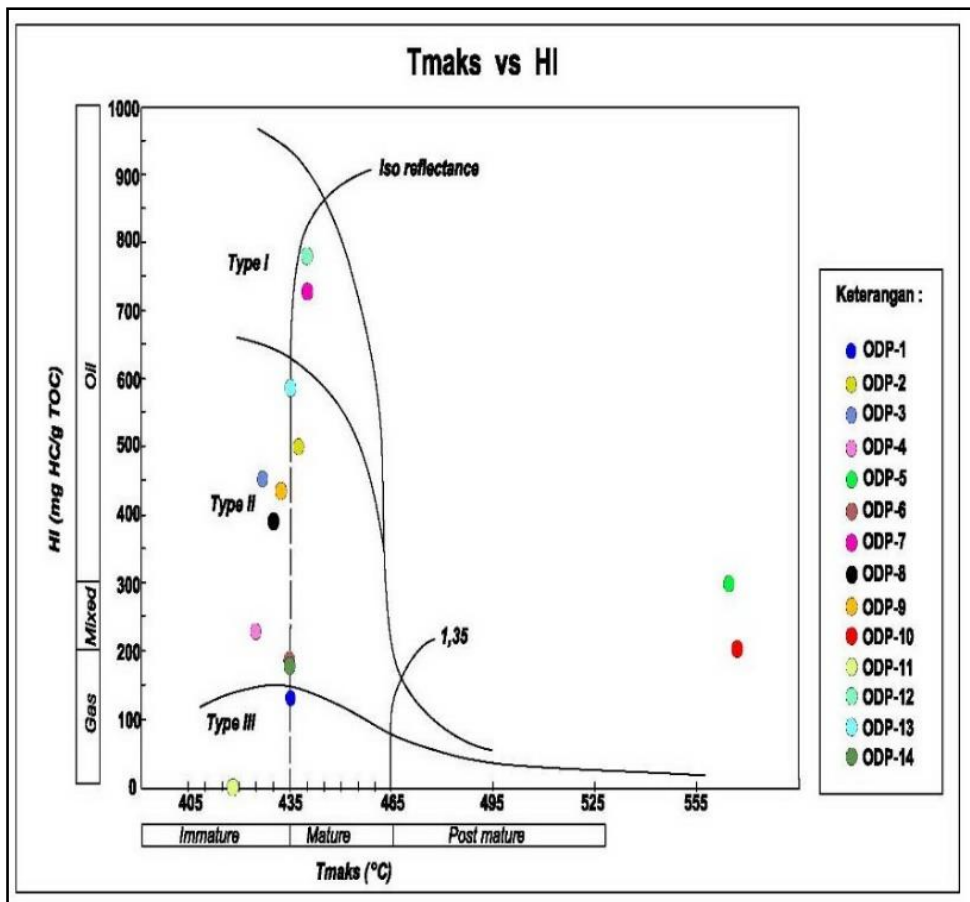

Gambar 4. Plot silang antara $\mathrm{T}_{\text {maks }}$ dan $\mathrm{HI}$ untuk mengetahui kematangan termal conto serpih di daerah penelitian. 
Dan sebaliknya, ada tujuh conto serpih (ODP-1, ODP-2, ODP-6, ODP-7, ODP-12, ODP-13, ODP-14) memiliki nilai $T_{\text {maks }}$ $435,1^{\circ} \mathrm{C}$ hingga $440,1^{\circ} \mathrm{C}$ mengindikasikan bahwa conto serpih tersebut dikategorikan matang (mature) dan dua conto serpih dengan notasi ODP-5 dan ODP-10 memiliki nilai $\mathrm{T}_{\text {maks }}$ berkisar $563,9^{\circ} \mathrm{C}$ hingga $564,4^{\circ} \mathrm{C}$ dikategorikan lewat matang (over mature).

Berdasarkan analisis fischer assay yang dilakukan pada conto serpih (Tabel 1), menunjukkan bahwa ada satu conto serpih yaitu notasi ODP-01 yang tidak menghasilkan minyak, sedangkan 13 conto serpih lainnya dapat menghasilkan minyak dengan kisaran sebesar 5 liter s.d. 90 liter minyak/ton serpih. Conto serpih yang tidak menghasilkan minyak tersebut, berdasarkan data hasil analisis pirolisis mengindikasikan bahwa conto serpih dengan notasi ODP-01 tersebut merupakan kerogen Tipe III yang memiliki kecenderungan untuk menghasilkan gas.

Secara keseluruhan, berdasarkan pembahasan hasil analisis TOC, Pirolisis, reflektansi vitrinit, dan fischer assay dapat diketahui bahwa conto serpih dengan notasi ODP-5 dan ODP-10 merupakan batuan sumber hidrokarbon yang baik sebagai batuan sumber hidrokarbon. Akan tetapi, conto serpih tersebut telah berada pada tahap lewat matang (over mature) dan diduga bahwa hidrokarbon yang dihasilkan dari conto serpih tersebut sebagian telah mengalami migrasi dari batuan sumbernya.

Estimasi sumber daya serpih di daerah penelitian mengacu pada SNI (Standar Nasional Indonesia), amandemen 1-SNI 13-5014-1998 tentang Klasifikasi Sumber daya dan Cadangan Batubara dengan menggunakan persamaan sebagai berikut:

$\mathrm{Vs}=\{$ Panjang $(\mathrm{m}) \times$ Lebar $(\mathrm{m}) \times$ Tebal $(\mathrm{m})\}$

Sumber daya serpih yang diperoleh dengan menggunakan persamaan tersebut di atas dikonversikan ke dalam satuan ton batuan dengan cara mengkalikan volume serpih terhadap berat jenis rata rata conto serpih yang dianalisis. Sumber daya serpih hasil penghitungan dikategorikan sebagai sumber daya hipotetik, yaitu sumber daya yang dihitung berdasarkan data yang memenuhi syarat-syarat yang ditetapkan untuk tahap survei tinjau.

Banyaknya kandungan minyak di dalam conto serpih dapat diketahui berdasarkan analisis fischer assay. Hasil analisis pada Tabel 1 memperlihatkan jumlah kandungan minyak dari 14 conto serpih hasil analisis berkisar 4-78 $\mathrm{l} /$ ton batuan. Kandungan minyak yang dipakai dalam estimasi kandungan minyak di daerah penelitian adalah kandungan minyak rata-rata tiap lapisan serpih (Tabel 2). Persamaan yang dipakai dalam estimasi kandungan minyak adalah:

$$
V m=\frac{(V s(\text { ton}) \times \text { Minyak (I/ton) }}{159}
$$

Keterangan:

$>V s$ adalah volume serpih.

$>V m$ adalah volume minyak.

$>1$ barel $=159$ liter .

Berdasarkan hasil penghitungan dengan menggunakan persamaan di atas, maka diperoleh sumber daya serpih di daerah penelitian sebesar 317.081.582 ton batuan dengan kandungan minyak sebesar 11.056.112.382 liter atau 69.535.298 barel (Tabel 2). 


\section{MAKALAH ILMIAH}

Tabel 2. Estimasi sumber daya serpih dan kandungan minyak di daerah penelitian.

\begin{tabular}{|c|c|c|c|c|c|c|c|c|}
\hline No. & Seam & $\begin{array}{l}\text { Panjang } \\
\text { (m) }\end{array}$ & $\begin{array}{l}\text { Lebar } \\
\text { (m) }\end{array}$ & $\begin{array}{l}\text { Tebal } \\
(\mathrm{m})\end{array}$ & $\begin{array}{c}\text { BJ } \\
\left.\text { (ton } / \mathrm{m}^{3}\right)\end{array}$ & $\begin{array}{c}\text { Rata-rata } \\
\text { Minyak / seam } \\
\text { batuan (I/ton) }\end{array}$ & $\begin{array}{l}\text { Sumberdaya } \\
\text { serpih (ton) }\end{array}$ & $\begin{array}{c}\text { Sumberdaya } \\
\text { Minyak } \\
\text { (barel)* }^{*}\end{array}$ \\
\hline 1 & A & 9743 & 363 & 12,5 & 2,3 & 21 & 101.680 .384 & 13.429 .485 \\
\hline 2 & B & 8265 & 267 & 17 & 2,3 & 57 & 86.284 .121 & 30.932 .043 \\
\hline 3 & C & 11551 & 324 & 15 & 2,3 & 31 & 129.117 .078 & 25.173 .770 \\
\hline \multicolumn{7}{|c|}{ Total Sumber Daya } & 317.081 .582 & 69.535 .298 \\
\hline
\end{tabular}

\section{KESIMPULAN}

Formasi pembawa endapan serpih di daerah penelitian adalah Formasi Sinamar berumur Oligosen. Endapan serpih di lokasi penelitian diperkirakan terdiri dari tiga lapisan dengan notasi Seam A, B dan $C$ dengan ketebalan lapisan diperkirakan berkisar \pm 10 hingga 25 meter. Endapan serpih di daerah penelitian memiliki kecenderungan menghasilkan minyak dan sedikit gas. Estimasi volume serpih adalah sebesar 317.081 .582 ton batuan dan volume minyak sebesar 69.535 .298 barel.

\section{UCAPAN TERIMA KASIH}

Penulis menyampaikan terima kasih kepada Kepala Pusat Sumber Daya Mineral Batubara dan Panas Bumi dan Kepala Bidang Batubara atas dukungan dalam pembuatan karya tulis ini, serta kepada Ujang Rustandi yang telah membantu dalam pembuatan peta dan rekan-rekan kerja yang telah memberikan masukan dan saran-saran sehingga tulisan ini dapat diselesaikan.

\section{DAFTAR PUSTAKA}

Cook, A.C. (1982): The origin and petrology of organic matter in coal, oil shales and petroleum source rocks, University Wollongong, Australia.

Crisp, P.T., Ellis, J., Hutton, A.C., Korth, J., Martin, F.A., Saxby, J.D. (1987): Australian oil shale: A compendium of geological and chemical data, University of Wollongong, Australia.

Dyni, J.R., 2006. Geology and resources of some world oil-shale deposits, Scientific investigation report 20055294, USGS, Reston, Virginia.
Gentzis, Thomas, 2012, A review of the thermal maturity and hydrocarbon potential of the Mancos and Lewis shale in part of New Mexico, USA, International Journal of coal geology, 64-75, Published by Elsevier B.V.

Harahap Bhakti, H., Syaiful B., Baharuddin, Suwarna N., Panggabean H., Simanjuntak T.O. (2003), Stratigraphic Lexicon of Indonesia, (Special Publication No. 29), Geological Research and Development Centre, Bandung.

Hutton, A.C. 1987: Petrographic classification of oil shales: International Journal of Coal Geology, 203-231, Published by Elsevier B.V.

Hutton, A.C. (2006): Organic petrography and classification of oil shales: Oil shales workshop, University of Wollongong, Australia.

Lee, Sunggyu, Speight, J.G., Loyalka, S.K., 2007. Handbook of alternative fuel technologies, CRC Press, Taylor and Francis Group.

Peters, K.E., Cassa, M.R. 1994: Applied source rock geochemistry: The petroleum system from source rock to trap, AAPG, Memoirs 60.

Rosidi, H.M.D., Tjokrosapoetro, S.,Pendowo, B., Gafoer, S., dan Suharsono, 1996, Peta Geologi Lembar Painan dan Bagian Timurlaut Muarasiberut, Sumatera, Pusat Penelitian dan Pengembangan Geologi, Bandung.

Tissot, B.P.,Welte, D.H. (1984): Petroleum formation and occurance, Springer Verlag, Berlin.

Tobing, R.L., 2015, Penyelidikan Bitumen Padat di Daerah Dusun Panjang, 


\section{MAKALAH ILMIAH}

Kabupaten Bungo, Provinsi Jambi, PSDG-Bandung.

Suryana. A., 2006, Inventarisasi Bitumen Padat dengan Outcrop Drilling Daerah Sungai Rumbia, Kabupaten Bungo, Provinsi Jambi, PSDGBandung.

Slatt, Roger, M., and Rodrigues, Norelis, 2010, Comparative Sequence Stratigraphy and Organic Geochemistry of North American Unconventional Gas Shales: Commonality or Coincidence, AAPG Hedberg Conference, Austin, Texas.

Suarez Isabel-Ruiz, Flores Deolinda, Filho Joao Graciano Mendoca, Hackley Paul, C., 2012, Review and update of the applications of organic petrology: Part 1, geological applications,
International Journal of Coal Geology, Elsevier.

Schieber Juergen, 2011, Shales, Encyclopedia of geobiology, Springer Verlag, J.Reitner and V. Thiel (Eds.), p.785-791.

Waples, D.W. 1985, Geochemistry in petroleum exploration, International Human Resources Development Coorporation, Boston.

Yen, T.F., Chilingarian, G.V. 1976: Oil shale, Elsevier, Amsterdam.

Zajuli Hermiyanto, M.H., Panggabean, H., 2013, Depositional environment of fine grained sedimentary rocks of the Sinamar Formation, Muara Bungo, Jambi, Indonesia Journal of Geologi, Vol. 8 No.1, p. 25-38.

\begin{tabular}{|ll|}
\hline Diterima & $:$ 16 Mei 2016 \\
Direvisi & $:$ 30 Juni 2016 \\
Disetujui & $: 5$ Agustus 2016
\end{tabular}

